Very early in his professional career Roalfe had been active in promoting regional cooperation, the importance of which he continued to emphasize. Later he was a leader in discussions on vital problems of law librarianship. His excellent book The Libraries of the Legal Profession (1953) stands as a landmark in the field of American law librarianship. In addition, Roalfe was the general editor of the fifth and sixth editions of How to Find the Law (1957 and 1965) and the author of numerous outstanding articles. In 1977 his book John Henry Wigmore: Scholar and Reformer was published, the first biography of one of the pre-eminent leaders in the field of Anglo-American law who also was world wide known for his interest in international and Japanese law.

Personally, Bob Roalfe was known for his human interests, his kindness, his love of nature, his gentle sense of humor and his warm feelings which he expressed in a volume of poems, Public Utterances (published in 1976).

Roalfe's record as the first president of the IALL was outstanding. He developed its first program which culminated in the Harvard Law School Meeting of June 24-25, 1961 (its Proceedings were published in 1962) and set the pattern for much of the later activities of the IALL.

It was only fitting that, in 1965, William R. Roalfe was selected honorary member of the International Association of Law Libraries, the only person so honored. He will be sorely missed by his family, his friends and by the profession.

\author{
Kurt SCHWERIN \\ Professor of Law Emeritus \\ \& Law Librarian Emeritus \\ Northwestern University \\ (IALL Board of Directors, 1965-1971)
}

\title{
Kate Wallach (1905-1979): An Obituary
}

Kate Wallach, Law Librarian and Professor Emerita at Louisiana State University, died at her home in Baton Rouge on 27 December 1979. A distinguished member of the International Association of Law Libraries, Kate Wallach was born in Krefeld, Germany, in 1905. She received her law degree from the University: of Cologne in 1931, and two years later was admitted to practice in Berlin.

The political situation in Germany forced her to emigrate to the United States in 1935, where she worked initially on drafts of the Restatement of Torts under Professor Harry Shulman of Yale University. She subsequently studied law at the University of Wisconsin, served on the Editorial Board of the Law Review, and had received her second law 
degree by 1940 . The following two years were spent working in the Law Library at the University of Michigan, while she completed the requirements for a degree in library science.

After three years as an attorney for the National Labor Relations Board in Washington, and following a special assignment in which she served as an attorney-advisor on international law aspects of war crimes for the Civil Affairs Division of the U.S. Army, Kate Wallach returned to law libraries as Assistant Librarian at the University of North Carolina. In 1949 she was appointed Law Librarian at L.S.U., where she remained until her retirement.

Kate Wallach's background in both common law and civil law systems, combined with an ability to work in at least five languages, led her to develop a library collection at L.S.U. that is unusually rich in foreign and comparative materials. She was the author of more than forty publications, including the standard manual for research in Louisiana law, as well as the compiler of a union list of Latin American legal materials. She was an authority on the French and Spanish sources of Louisiana law.

Prominent within her profession, Kate Wallach served as President of both the American Association of Law Libraries (1966-1967) and the Louisiana Library Association (1960-1961). She held the position of Professor of Law at L.S.U. from 1964, regularly offering a variety of seminars in comparative law. In 1970 she relinquished her administrative responsibilities, but remained as Comparative Law Librarian until her retirement in 1975 .

On her retirement Dean Paul M. Hebert remarked, "As library administrator, law teacher, scholar, comparatavist, as devoted friend to a generation of students, and as a national leader among law librarians, Kate Wallach has made contributions to legal education in general and to the development of Louisiana law in particular that can never be erased." To this may properly be added her dedication to the international aspects of legal scholarship. She is remembered as a dear and distinguished colleague by her friends in many countries.

LANCE E. Dickson

Librarian and Professor

Louisiana State University Law Center

\section{Jurij Fedynskyj (1912-1979): In Memoriam}

Dr. Jurij Fedynskyj, the recently retired Associate Librarian and Associate Professor of Law at Indiana University in Bloomington, died November 25, 1979 at the age of 67. He died of cancer after a long illness, with a regret that fate did not allow him enough time to write the 